\title{
Factors influencing utilization of municipal solid waste compost among urban farmers in western Uganda
}

\author{
Juliet Kiiza Kabasiita 1* $\mathbb{0}$, Geoffrey Maxwell Malinga ${ }^{2}$, Julius C. W. Odongo ${ }^{1}$ and Emmanuel Opolot ${ }^{3}$
}

\begin{abstract}
Background: Effective management of solid waste is one of the most serious environmental problems confronting urban governments in developing countries due to insufficient financial resources and institutional capacity to provide basic solid waste management infrastructure, impoverished urban populations, low rates and coverage of collection, and rising food consumption rates. Composting has been touted as the most economical solution for reducing organic fraction of urban waste volumes while releasing vital nutrients for the soils. However, there is a paucity of information on utilization and associated factors of urban wastes in Uganda. This study aims to assess the level of utilization of Municipal Solid Waste (MSW) compost produced from Clean Development Mechanism (CDM) plants and associated factors among farmers in Fort Portal and Mbarara Municipalities, western Uganda.
\end{abstract}

Methods: Data was collected using a cross-sectional survey from 359 and 361 randomly selected farmers in Mbarara and Fort Portal, respectively. A semi-structured questionnaire was employed to collect quantitative data and analyzed statistically using SPSS and STATA statistical programs. Probit model was used to determine factors that influence farmers' decisions to utilize MSW compost as a soil conditioner.

Results: The findings revealed a very low level of utilization in both municipalities, 1.7\% in Fort Portal and 2.2\% in Mbarara. The results indicated that annual farm income, access to other soil conditioners, experience with the use of fertilizers, membership to a farmers' group and the cost of MSW compost significantly influenced farmers' decision to use MSW compost.

Conclusions: The findings call for government investment in policies aimed at increasing the level of utilization of the MSW compost by improving accessibility to soil conditioners, creating opportunities for maximizing household incomes, farmer-to-farmer experience sharing, dissemination of information through extension programmes and other innovative communication approaches, operationalization of farmers' groups and introduction of subsidy schemes on the price of compost through operational tax waivers in urban areas of Uganda. Finally, to guarantee quality and to improve the adoption of compost generated at the CDM plants, there is a need for research to assess the quality of MSW compost, undertake a supply chain analysis and cost-benefit study and set a price commensurate with the quality, and develop guidelines and rates of application of the MSW compost.

Keywords: MSW compost, Urban areas, Solid waste management

*Correspondence: jkab75@yahoo.co.uk

1 Department of Agronomy, Faculty of Agriculture and Environment, Gulu University, P. O. Box 166, Gulu, Uganda

Full list of author information is available at the end of the article

\section{Background}

In Sub-Saharan Africa, the urban population is increasing at an astonishing rate (Saghir and Santoro 2018). For example, in Uganda, the urban population has grown original author(s) and the source, provide a link to the Creative Commons licence, and indicate if changes were made. The images or other third party material in this article are included in the article's Creative Commons licence, unless indicated otherwise in a credit line to the material. If material is not included in the article's Creative Commons licence and your intended use is not permitted by statutory regulation or exceeds the permitted use, you will need to obtain permission directly from the copyright holder. To view a copy of this licence, visit http://creativecommons.org/licenses/by/4.0/. The Creative Commons Public Domain Dedication waiver (http://creativeco mmons.org/publicdomain/zero/1.0/) applies to the data made available in this article, unless otherwise stated in a credit line to the data. 
by about 4.5 million between 2002 ( 2.9 million) and $2014(7.4 \mathrm{~m})$ (UBOS 2016) accelerating the amount of waste generation (Aryampa et al. 2019) and the demand for food (Sabiiti and Katongole 2016, 2014). Effective management of municipal solid waste (MSW), especially organic waste is a challenge to many urban areas in Uganda (Komakech 2014a, b). Most solid wastes are burnt, dumped indiscriminately in landfills leading to pollution of the air, soil and water bodies, posing health and livelihood risks to many urban dwellers (Komakech et al. 2014b). Treatment of the organic fraction of the MSW through composting is one feasible and costeffective method of reducing waste volumes while releasing vital nutrients for the soils of developing countries (Komakech 2014a; Danso et al. 2017; Nigussie et al. 2015; Tweib et al. 2011). According to Tweib et al. (Tweib et al. 2011), composting can be carried out with little capital and operating costs. For example, a recent economic estimation by Romero et al. (Romero et al. 2013) in Spain showed that the production cost of raw compost leachate as fertilizer could be as low as $0.67 €$ per litre compared to $4.61 €$ per litre for commercial fertilizer.

There is potential for organic waste and MSW compost utilization and management through urban agriculture in Uganda (Komakech 2014a; Nsimbe et al. 2018). Treatment of MSW is important to reduce the overuse of chemical fertilizers in agriculture since they cause severe pollution of water resources (Diacono and Montemurro 2011; Ojo et al. 2014; Savci 2012; Udeigwe et al. 2015) and a decrease in the amount of soil organic matter (Massah and Azadegan 2016; Roba 2018; Wu et al. 2020). Moreover, results from the annual agricultural survey carried out in 2018 (UBOS 2018) indicate that $77 \%$ of the households in Uganda use organic fertilizers (e.g., livestock manure, crop residues and ash) to improve agricultural production. The use of the derived organic compost represents an appropriate win-win waste management strategy and sustainable soil fertility management practice (Kumar et al. 2020; Rogger et al. 2011), especially for farmers in urban areas (Komakech 2014a; Menyuka et al. 2018).

With the aims to address the mounting solid waste management problems in Ugandan municipalities, reduce greenhouse gas emissions from open dumping landfills and use the generated compost as a safe alternative fertilizer for crop production, the Uganda National Environment Management Authority (NEMA) with support from the World Bank and the government of Netherlands initiated a municipal solid waste composting project in 2005 under the Clean Development Mechanism (CDM) in nine municipalities including Mukono, Jinja, Mbale, Soroti, Lira, Mbarara, Kasese, Kabale, and Fort Portal in the first phase of the project (Lederer et al. 2015; Okot-Okumu and Nyenje 2011). As part of the cost-recovery plan, each municipality was expected to generate revenue through the sale of the recyclables such as plastics to urban residents and composts to its farmers. To sustain the functionality of these compost plants, there is a need to understand whether or not urban farmers utilize these MSW compost as a soil conditioner in agricultural production and the factors that influence its utilization. Studies on the use and determinants of use of agricultural technologies (Melesse 2018; Mwangi and Kariuki 2015) and soil fertility improvement (Abebe and Debebe 2019; Ali et al. 2018; Babasola et al. 2018; Nazziwa-Nviiri et al. 2017) have been done in Uganda, Ghana, Nigeria and Ethiopia. These studies have shown that socio-demographic factors (Mwangi and Kariuki 2015; Abebe and Debebe 2019; Babasola et al. 2018) influenced the use of organic fertilizers. In Uganda, previous studies have mostly involved the use of homemade compost mainly from manure and crop residues, kitchen refuse (Nsimbe et al. 2018), chemical fertilizers (Nazziwa-Nviiri et al. 2017) and fecal sludge (Danso et al. 2017). However, to our knowledge, there is limited evidence about the utilization of MSW compost as a soil conditioner in crop production by urban farmers where CDM plants have been established and associated factors in Uganda. Such information is important in guiding investment decisions by farmers and businessmen in MSW compost reuse businesses through the conversion of waste to organic fertilizers, and urban planning. This study aimed to assess the current utilization of the MSW compost from CDM plants in agricultural production and its associated factors among urban farmers in Mbarara and Fort Portal municipalities of Uganda. Urban areas in this study have been defined as those areas under the municipality administration according to the Uganda National Urban Policy (MoLHUD 2017).

\section{Methods \\ Study area}

The study was conducted in Fort Portal and Mbarara Municipalities of western Uganda. These municipalities were purposively selected because both have the highest rates of organic fertilizer use (39.6\%) as reported by UBOS (UBOS 2018), have CDM project compost plants, with each plant capable of composting between 2.3-3.5\% of the wastes collected per day (NEMA 2017). The mean annual rainfall and mean annual temperature in Mbarara is $832 \mathrm{~mm}$ and $21{ }^{\circ} \mathrm{C}$, respectively, and soils are mostly Luvisols and acidic clay loam (Kaizzi 2014; Wortmann and Eledu 1999). Fort Portal, receives a mean annual rainfall of $1310 \mathrm{~mm}$, with a mean temperature of $20{ }^{\circ} \mathrm{C}$ (Wortmann and Eledu 1999), and the soils are characterized as Lixic Ferralsols (Wortmann and Eledu 1999; Okello-Oleng et al. 2021). 


\section{Sampling design and sample size}

A cross-sectional survey was conducted between February and April 2019 to collect primary data from farming household heads or their spouses. All the divisions and villages in the study municipalities were included in the sampling frame. From each village, a list of farmers, generated with the help of local council chairpersons was used as a sampling frame. We determined the sample size for the number of households to participate in the survey using the Krejcie and Morgan (1970) table, covering both MSW compost users and non-users. Individual urban farmers (farmers above 18 years) from each village were randomly selected and interviewed using a semi-structured questionnaire (Nigussie et al. 2015). The questionnaire was pretested with 20 farmers from Fort Portal Municipality and appropriate modifications were made. The questions asked included the socio-demographic characteristics of the household heads such as age in years, gender, educational level, marital status, land size, land ownership, land tenure, farming experience, access to extension services, access to infrastructure, access to credit facilities, engagement in non-farm activities, annual household income from farming, farmer experience with compost, number of household members and access to other soil conditioners (e.g., livestock manure, crop residues and ash). During the interview process, individual farmers were asked whether or not they utilized MSW compost in their farms. Furthermore, farmers were asked whether or not they were willing to pay for MSW compost and cost per Kg they were willing to pay for such compost. Field observations and discussions with key informant respondents (17 from Fort Portal and 32 from Mbarara) were used to supplement the household interviews.

\section{Study variables}

The dependent variable in the study was the level of utilisation of the MSW compost by farmers ( 1 if utilizing MSW compost, 0 otherwise, Table 1). The independent variables were chosen based on previous studies (Abebe and Debebe 2019; Babasola et al. 2018; Akpan et al. 2012; Huang and Karimanzira 2018; Zhou et al. 2010) and they included socio-demographic factors (e.g., gender, age, marital status, level of education, number of people in the household, farming experience, access to extension services, access to good infrastructure, access to credit facilities, access to markets, membership of farmer association, engagement in non-farm activities, land ownership, farm size, the land tenure system, level of income, access to other soil conditioners (e.g., livestock manure, crop residues and ash), experience in the use of compost, willingness to take part in compost making and cost per $\mathrm{Kg}$ of compost the farmer was able to pay.

\section{Data analysis}

Primary data was entered into Excel and imported into IBM SPSS version 25 and STATA version 14. Descriptive statistic using percentages was used to express the level of utilization of MSW compost. A probit regression model was used to analyse factors that influence respondents' utilization of MSW compost. Multicollinearity among the explanatory variables used in the model was tested using correlation matrices (Nigmatullin 2008). We determined the statistical significance at a p-value $\leq 0.05$. In the probit model, the categorical (usually dichotomous) dependent variable was modelled as a linear (or log-linear) function of a combination of explanatory variables (Noreen 1988). The probit model assumes that while we only observe the values of 0 and 1 for the variable $Y$, there is a latent, unobserved continuous variable $\mathrm{Y}^{*}$ that determines the value of Y (Sebopetji and Belete 2009). The probit model was preferred over the logit model because it includes believable error term distribution as well as realistic probabilities (Nagler 1994). The Probit model is specified as follows:

Let us suppose $\mathrm{Yi}$ is a binary response variable with only two possible outcomes ( 1 if the farmer is utilizing MSW compost and 0 otherwise).

Consider also a vector of independent variables xi which is assumed to influence Yi.

Then the probit model takes the form:

$$
\operatorname{Pr}\left(Y_{i}=1 \mid x_{i}\right)=F\left(\beta^{\prime} x_{i}\right)=\Phi\left(\beta^{\prime} x_{i}\right)
$$

where $\operatorname{Pr}$ denotes the probability that an individual uses compost or not, $\mathrm{Y}_{i}$ is the binary choice variable representing use and $\Phi$ is the cumulative distribution function of the standard normal distribution. $\beta$ is a vector of unknown parameters.

It is assumed that the latent variable $Y_{i}^{*}$ can be specified as follows:

$$
Y_{i} *=\beta_{0}+\sum_{n=1}^{N} \beta_{n} x_{n i}+u_{i}
$$

And that:

$\mathrm{Y}_{\mathrm{i}}=1$ if $\mathrm{Y}^{*}>0$.

$Y_{i}=0$ otherwise.

where $\mathrm{x}_{i}$ represents a vector of explanatory variables, $\mathrm{u}_{i}$ is a random disturbance term, $\mathrm{N}$ is the total sample size, and $\beta$ 
Table 1 The description of the variables used in the study and their expected signs

\begin{tabular}{|c|c|c|c|c|}
\hline Variable & Description & Definition and unit & Expected sign & References \\
\hline Dependent variable & $\begin{array}{l}\text { Utilization of MSW compost in } \\
\text { percentage }\end{array}$ & $\begin{array}{l}1 \text { if utilizing MSW compost } \\
0 \text {, otherwise }\end{array}$ & & \\
\hline \multicolumn{5}{|l|}{ Independent variable } \\
\hline Gender & Gender of household head & $\begin{array}{l}1 \text { if the household head }(\mathrm{HH}) \text { is } \\
\text { male, } 0 \text { if otherwise }\end{array}$ & \pm & $\begin{array}{l}\text { Abebe and Debebe 2019; Mukai } \\
\text { 2017) }\end{array}$ \\
\hline Age & $\begin{array}{l}\text { Age of the household head (in } \\
\text { years) }\end{array}$ & $\begin{array}{l}1 \text { if less than } 18,2 \text { for } 18-36 \text {, and } 3 \\
\text { for greater than } 36\end{array}$ & - & $\begin{array}{l}\text { Zhou et al. 2010; Martey et al. 2014; } \\
\text { Li et al. 2020) }\end{array}$ \\
\hline Marital status & Marital status of household head & 1 if couple; 0 otherwise & \pm & Ali et al. 2018; Mensah et al. 2018) \\
\hline Education & $\begin{array}{l}\text { Level of education of the house- } \\
\text { hold head }\end{array}$ & $\begin{array}{l}0 \text { for illiterate, } 1 \text { for primary, } 2 \text { for } \\
\text { secondary and } 3 \text { for tertiary }\end{array}$ & \pm & Mwangi and Kariuki 2015) \\
\hline Household size & $\begin{array}{l}\text { Number of people in the house- } \\
\text { hold }\end{array}$ & $\begin{array}{l}\text { Number ( } 1 \text { for less than } 3,2 \text { for } \\
3-6,3 \text { for greater than } 6)\end{array}$ & \pm & Ullah et al. 2018) \\
\hline Extension services & Access to extension services & $\begin{array}{l}1 \text { if } \mathrm{HH} \text { has access to extension } \\
\text { services, } 0 \text { otherwise }\end{array}$ & + & $\begin{array}{l}\text { Abebe and Debebe 2019; Udimal } \\
\text { et al. 2017) }\end{array}$ \\
\hline Infrastructure & $\begin{array}{l}\text { Access to infrastructure (roads, } \\
\text { storage areas etc.) }\end{array}$ & 1 if $\mathrm{HH}$ has access, 0 otherwise & + & Assefa and Gezahegn 2009) \\
\hline Credit facilities & Access to credit facilities & 1 if has access, 0 otherwise & + & $\begin{array}{l}\text { Abebe and Debebe 2019; Udimal } \\
\text { et al. 2017) }\end{array}$ \\
\hline Market & $\begin{array}{l}\text { Access to market for produce } \\
\text { from farm }\end{array}$ & 1 if has market, 0 otherwise & + & Assefa and Gezahegn 2009) \\
\hline Farmer association & $\begin{array}{l}\text { Membership of farmers' associa- } \\
\text { tion }\end{array}$ & 1 if $\mathrm{HH}$ is a member, 0 otherwise & + & $\begin{array}{l}\text { Martey et al. 2014; Mensah et al. } \\
\text { 2018) }\end{array}$ \\
\hline Income & $\begin{array}{l}\text { Annual income from farming in } \\
\text { Uganda shillings }\end{array}$ & $\begin{array}{l}1 \text { if less than } 200,000,2 \text { for } \\
200,000-400,000 \text { and } 3 \text { if greater } \\
\text { than } 400,000\end{array}$ & + & Huang and Karimanzira 2018) \\
\hline Non-farm activities & Engaged in non-farm activities & $\begin{array}{l}1 \text { if the household is engaged in } \\
\text { non-farm activities, } 0 \text { otherwise }\end{array}$ & + & $\begin{array}{l}\text { Mwangi and Kariuki 2015; Ullah } \\
\text { et al. 2018) }\end{array}$ \\
\hline Farming experience & Farming experience (years) & $\begin{array}{l}1 \text { for less than } 5,2 \text { for } 5-10 \text { and } 3 \\
\text { if greater than } 10\end{array}$ & + & $\begin{array}{l}\text { Huang and Karimanzira 2018; } \\
\text { Mensah et al. 2018) }\end{array}$ \\
\hline Land ownership & Land ownership & 1 if land is available, 0 otherwise & + & Huang and Karimanzira 2018) \\
\hline Land size & Total size of the farmland (acres) & $\begin{array}{l}\text { Acres ( } 1 \text { for less than } 2,2 \text { for } 2-4 \\
\text { and } 3 \text { for greater than } 4 \text { acres) }\end{array}$ & + & Huang and Karimanzira 2018) \\
\hline Land tenure & Household land tenure system & $\begin{array}{l}\text { Land tenure ( } 1 \text { for customary, } 2 \\
\text { for freehold, } 3 \text { for leasehold and } \\
4 \text { for Mailo) }\end{array}$ & + & Nambiro and Okoth 2013) \\
\hline Access to soil conditioner & $\begin{array}{l}\text { Household access to soil condi- } \\
\text { tioner }\end{array}$ & 1 if $\mathrm{HH}$ has access, 0 otherwise & + & Mwangi and Kariuki 2015) \\
\hline Experience of compost & $\begin{array}{l}\text { Experience with compost ferti- } \\
\text { lizer use in years }\end{array}$ & $\begin{array}{l}1 \text { if the } \mathrm{HH} \text { applied compost, } 0 \\
\text { otherwise }\end{array}$ & + & Mukai 2017) \\
\hline $\begin{array}{l}\text { Cost at which farmer } \\
\text { is willing to pay for } \\
\text { compost }\end{array}$ & $\begin{array}{l}\text { Cost at which farmer is willing to } \\
\text { pay for use of compost as a soil } \\
\text { conditioner }\end{array}$ & $\begin{array}{l}1 \text { if willing to contribute money, } \\
0 \text { otherwise }\end{array}$ & + & Mwangi and Kariuki 2015) \\
\hline Price of compost & Cost of compost per kilogram & $\begin{array}{l}1 \text { for less than } 100,2 \text { if } 100-200,3 \\
\text { for } 200-500 \text { and } 4 \text { for } \geq 500\end{array}$ & + & $\begin{array}{l}\text { Nazziwa-Nviiri et al. 2017; Akpan } \\
\text { et al. 2012) }\end{array}$ \\
\hline
\end{tabular}

is a vector of unknown parameters to be estimated by the method of maximum likelihood.

Model specification; where,

$\mathrm{Yi}=$ is the probability of utilization of MSW compost (1 if the farmer is utilizing MSW compost, 0 otherwise); X1,

$$
\begin{aligned}
\mathrm{Yi}= & \beta 0+\beta 1 \mathrm{X} 1+\beta 2 \mathrm{X} 2+\beta 3 \mathrm{X} 3+\beta 4 \mathrm{X} 4+\beta 5 \mathrm{X} 5+\beta 6 \mathrm{X} 6+\beta 7 \mathrm{X} 7+\beta 8 \mathrm{X} 8+\beta 9 \mathrm{X} 9+\beta 10 \mathrm{X} 10+\beta 11 \mathrm{X} 11 \\
& +\beta 12 \mathrm{X} 12+\beta 13 \mathrm{X} 13+\beta 14 \mathrm{X} 14+\beta 15 \mathrm{X} 15+\beta 16 \mathrm{X} 16+\beta 17 \mathrm{X} 17+\beta 18 \mathrm{X} 18+\beta 19 \mathrm{X} 19+\beta 20 \mathrm{X} 20+\mathrm{ui}
\end{aligned}
$$


gender of household head (male $=1$, otherwise 0 ); X2, age of the household head (year); X3, marital status (1 if couple, 0 otherwise); X4, education of household head; X5, household size; $X 6$, access to extension services; $X 7$, access to infrastructure; $\mathrm{X} 8$, access to credit facilities; X9, access to market for produce; X10, membership of farmer association; X11, annual income from farming in Uganda shillings; $\mathrm{X} 12$, engagement in non-farm activities; X13, farming experience; X14, land ownership (1 if land is available, 0 otherwise); X15, total size of farmland in acres; X16, household land tenure system; X17, household access to other soil conditioners ( 1 if household has access, 0 otherwise); $\mathrm{X} 18$, experience with compost fertilizer use in years (1 if the household applied compost, 0 otherwise); X19, cost at which farmer is willing to pay for use of MSW compost as a soil conditioner ( 1 if willing to contribute money, otherwise 0 ); $\mathrm{X} 20$, cost per kilogram of compost; $\beta 0$ is the regression coefficient and ei is random error term. The model estimates marginal effects of an explanatory variable on the expected value of the dependent variable and the coefficients are more informative and useful for policy decision making (Anang 2016).

The marginal effects are estimated by differentiating Eq. (1) with respect to $x_{i}$ according to Greene (Greene 2000).

$$
\frac{\partial y}{\partial x}=\phi\left(\beta^{\prime} x_{i}\right) \beta_{i}
$$

where $\phi$ represents the probability density function of the standard normal distribution.

\section{Results}

\section{Socio-demographic characteristics of respondents} and utilization of MSW compost

The study revealed that among the study participants in Fort Portal, the majority were females $(56.5 \%)$, were aged above 36 years $(56.2 \%)$, were married $(71.5 \%)$, had no experience in composting (73.7\%), had access to extension services (67.6\%), had access to other soil conditioners (60.1\%), had access to infrastructure (good roads and storage, 94.2\%), had access to credit facilities $(74.2 \%)$ and markets (93.6\%), were engaged in nonfarm activities (78.8\%), owned land (90.3\%), and had less than two acres of land (57.6\%). Nevertheless, only $35.5 \%$ were members of farmers' associations. In Mbarara, the majority were males $(51.8 \%)$, married $(65.7 \%)$, had secondary level education (34.4\%), had a household size of 3-6 persons (45.5\%), had access to a soil conditioner (62.7\%), had access to extension services (60.4\%), had access to good infrastructure (87.5\%), had access to credit facilities $(70.8 \%)$ and markets (83.6\%), had prior experience in composting (44.0\%), earned an annual income of less than 200,000 Uganda shillings (56 US dollars) from farming (46.8\%), were involved in non-farm activities $(66.6 \%)$ and owned land (77.2\%) of less than two acres (33.1\%). Only $30.6 \%$ were members of the farmer associations and had a farming experience of more than 10 years (24.6\%) (Table 2). Also, in this study, only $1.7 \%$ of the farmers in Fort Portal municipality utilized MSW compost compared to $2.2 \%$ of the farmers in Mbarara municipality.

\section{Factors associated with utilization of MSW compost}

The probit regression results of factors influencing farmers' utilization of MSW compost in Fort Portal and Mbarara municipalities are presented in Table 3. The likelihood ratio chi-square $\left(\mathrm{LR} \mathrm{Chi}{ }^{2}\right)$ for the model was statistically significant at $1 \%$ level of significance, which revealed the model had good explanatory power. The validity of the Probit model in estimating utilization of MSW compost is consistent with a related study from Ghana (Danso et al. 2017). Results from the Probit regression model showed that five out of the 20 variables included in the model were positively significant in influencing the utilization of MSW compost in Mbarara, whereas four variables were positively significant in influencing farmers' decision to utilize MSW compost in Fort Portal (Table 3). In Fort Portal, the factors that were positively significant in influencing farmers' decision to use MSW compost were the level of income from farming activities, access to other soil conditioner, the experience a farmer had in using a soil conditioner. The cost of compost was negatively significant in influencing farmers' decision to use MSW compost. However, in Mbarara, the level of income from farming activities, access to other soil conditioners and the experience a farmer had in using a soil conditioner significantly and positively influenced farmers' decision to use MSW compost. Membership of a farmer association and the cost per $\mathrm{Kg}$ of compost were the factors that significantly and negatively influenced the decision to use MSW compost (Table 3).

\section{Discussion}

The level of utilization of CDM compost found in our study $(1.7 \%$ for Fort Portal Municipality and $2.2 \%$ for Mbarara Municipality) were much lower than what was reported (25\%) for municipal solid waste compost in urban and peri-urban areas of Accra, Ghana (Danso et al. 2006). The generally low utilization of the compost in urban areas might be explained by constraints associated with urban compost use (e.g., poor quality of compost including broken bottles and polythene, price and transportation costs, high water requirements of plants following compost application and absence of markets for organically produced crops), negative perceptions 
Table 2 Socio-demographic characteristics of the study participants and utilization of MSW compost in Fort Portal and Mbarara municipalities, western Uganda, 2018 ( $n=359$ for Mbarara and 361 for Fort Portal)

\begin{tabular}{|c|c|c|c|c|c|}
\hline \multirow[t]{2}{*}{ Variable } & \multirow[t]{2}{*}{ Description } & \multicolumn{2}{|c|}{ Mbarara } & \multicolumn{2}{|c|}{ Fort Portal } \\
\hline & & $\mathbf{N}$ & Frequency (\%) & $\mathbf{N}$ & Frequency (\%) \\
\hline \multirow[t]{2}{*}{ Gender of household head } & Female & 173 & 48.2 & 204 & 56.5 \\
\hline & Male & 186 & 51.8 & 157 & 43.5 \\
\hline \multirow[t]{3}{*}{ Age (years) } & Below 18 & 3 & 0.8 & 1 & 0.3 \\
\hline & $18-36$ & 200 & 55.7 & 157 & 43.5 \\
\hline & Above 36 & 156 & 43.5 & 203 & 56.2 \\
\hline \multirow[t]{4}{*}{ Marital status } & Single & 73 & 20.3 & 57 & 15.8 \\
\hline & Married & 236 & 65.7 & 258 & 71.5 \\
\hline & Divorced/Separated & 12 & 3.3 & 20 & 5.5 \\
\hline & Widowed & 38 & 10.6 & 26 & 7.2 \\
\hline \multirow[t]{4}{*}{ Education } & No formal education & 32 & 8.9 & 36 & 10 \\
\hline & Primary & 106 & 29.5 & 92 & 25.5 \\
\hline & Secondary & 123 & 34.3 & 188 & 52.1 \\
\hline & Tertiary & 98 & 27.3 & 45 & 12.5 \\
\hline \multirow[t]{3}{*}{ Family size } & Below 3 & 99 & 27.6 & 51 & 14.4 \\
\hline & 3 to 6 & 163 & 45.4 & 158 & 43.8 \\
\hline & Above 6 & 97 & 27 & 151 & 41.8 \\
\hline \multirow[t]{2}{*}{ Access to extension services } & Yes & 142 & 39.6 & 244 & 67.6 \\
\hline & No & 217 & 60.4 & 117 & 32.4 \\
\hline \multirow[t]{2}{*}{ Access to infrastructure } & Yes & 314 & 87.5 & 340 & 94.2 \\
\hline & No & 45 & 12.5 & 21 & 5.8 \\
\hline \multirow[t]{2}{*}{ Access to credit facilities } & Yes & 254 & 70.8 & 268 & 74.2 \\
\hline & No & 105 & 29.2 & 93 & 25.8 \\
\hline \multirow[t]{2}{*}{ Access to market for produce } & Yes & 300 & 83.6 & 338 & 93.6 \\
\hline & No & 59 & 16.4 & 23 & 6.4 \\
\hline \multirow[t]{2}{*}{ Membership of farmer association } & Yes & 110 & 30.6 & 128 & 35.5 \\
\hline & No & 249 & 69.4 & 233 & 64.5 \\
\hline \multirow[t]{3}{*}{ Annual income from farming in Uganda shillings } & Less than 200,000 & 168 & 46.8 & 37 & 10.2 \\
\hline & $200,000-400,000$ & 137 & 38.2 & 158 & 44.6 \\
\hline & Greater than 400,000 & 54 & 15 & 163 & 45.2 \\
\hline \multirow[t]{2}{*}{ Engagement in non-farm activities } & Yes & 239 & 66.6 & 284 & 78.7 \\
\hline & No & 120 & 33.4 & 77 & 21.3 \\
\hline \multirow[t]{3}{*}{ Farming experience } & Less than 5 & 138 & 38.4 & 97 & 26.9 \\
\hline & 5 to 10 & 133 & 37 & 129 & 35.7 \\
\hline & Above 10 & 88 & 24.6 & 135 & 37.4 \\
\hline \multirow[t]{2}{*}{ Land ownership } & Owns land & 277 & 77.2 & 326 & 90.3 \\
\hline & Does not own land & 82 & 22.8 & 35 & 9.7 \\
\hline \multirow[t]{4}{*}{ Total size of farmland in acres } & Below 2 & 119 & 33.1 & 208 & 57.6 \\
\hline & 2 to 4 & 101 & 28.1 & 124 & 34.3 \\
\hline & Above 4 & 75 & 20.9 & 26 & 7.2 \\
\hline & Not applicable & 64 & 17.8 & 3 & 0.8 \\
\hline \multirow[t]{4}{*}{ Household land tenure system } & Customary & 145 & 40.4 & 48 & 13.3 \\
\hline & Freehold & 138 & 38.4 & 213 & 59 \\
\hline & Leasehold & 18 & 5 & 70 & 19.4 \\
\hline & Mailo & 6 & 1.7 & 30 & 8.3 \\
\hline \multirow[t]{2}{*}{ Household access to soil amendment } & Yes & 225 & 62.7 & 217 & 60.1 \\
\hline & No & 134 & 37.3 & 144 & 39.9 \\
\hline Experience with compost fertilizer use in years & No experience & 158 & 44 & 266 & 73.7 \\
\hline
\end{tabular}


Table 2 (continued)

\begin{tabular}{|c|c|c|c|c|c|}
\hline \multirow[t]{2}{*}{ Variable } & \multirow[t]{2}{*}{ Description } & \multicolumn{2}{|c|}{ Mbarara } & \multicolumn{2}{|c|}{ Fort Portal } \\
\hline & & $\mathbf{N}$ & Frequency (\%) & $\mathbf{N}$ & Frequency (\%) \\
\hline & Less than 1 & 39 & 10.9 & 35 & 9.7 \\
\hline & 1 to 3 & 66 & 18.4 & 22 & 6.1 \\
\hline & Above 36 & 64 & 17.8 & 38 & 10.5 \\
\hline \multirow{2}{*}{$\begin{array}{l}\text { Cost at which farmer is willing to pay for use of soil } \\
\text { amendment }\end{array}$} & Yes & 203 & 56.5 & 232 & 64.3 \\
\hline & No & 156 & 43.5 & 129 & 35.7 \\
\hline \multirow[t]{5}{*}{ The price per kg a farmer can pay } & Less than 100 & 130 & 36.2 & 124 & 34.3 \\
\hline & $100-200$ & 44 & 12.3 & 100 & 27.7 \\
\hline & Greater than 200 & 17 & 4.7 & 7 & 1.9 \\
\hline & Should be given for free & 13 & 3.6 & 1 & 0.3 \\
\hline & Not applicable & 155 & 43.2 & 129 & 35.7 \\
\hline \multirow[t]{2}{*}{ Utilization of MSW compost } & Yes & 8 & 2.2 & 6 & 1.7 \\
\hline & No & 351 & 97.8 & 355 & 98.3 \\
\hline
\end{tabular}

Table 3 Probit regression results of factors influencing farmers' decision to use MSW compost in Fort Portal and Mbarara municipalities, Uganda

\begin{tabular}{|c|c|c|c|c|c|c|c|c|}
\hline \multirow[t]{2}{*}{ Independent variables } & \multicolumn{4}{|l|}{ Fort Portal } & \multicolumn{4}{|l|}{ Mbarara } \\
\hline & Coefficient & Standard Error & $\mathrm{P}>|\mathrm{z}|$ & $\begin{array}{l}\text { Marginal } \\
\text { effect (dy/ } \\
d x)\end{array}$ & Coefficient & Standard Error & $P>|z|$ & $\begin{array}{l}\text { Marginal } \\
\text { effect (dy/ } \\
d x)\end{array}$ \\
\hline Gender of household head & 0.256 & 0.244 & 0.294 & 0.03 & 0.234 & 0.246 & 0.343 & 0.027 \\
\hline Age of household head & -0.073 & 0.127 & 0.567 & -0.008 & -0.036 & 0.129 & 0.78 & -0.004 \\
\hline Marital status of household head & -0.019 & 0.168 & 0.912 & -0.002 & -0.016 & 0.168 & 0.924 & -0.002 \\
\hline Level of education & -0.001 & 0.132 & 0.993 & $<0.001$ & -0.027 & 0.132 & 0.841 & -0.003 \\
\hline Family size & 0.152 & 0.144 & 0.292 & 0.018 & 0.166 & 0.146 & 0.257 & 0.019 \\
\hline Access to extension services & 0.168 & 0.303 & 0.581 & 0.019 & 0.232 & 0.307 & 0.449 & 0.027 \\
\hline Access to infrastructure & 0.517 & 0.554 & 0.351 & 0.061 & 0.522 & 0.561 & 0.352 & 0.061 \\
\hline Access to credit facilities & 0.418 & 0.315 & 0.185 & 0.049 & 0.399 & 0.317 & 0.208 & 0.046 \\
\hline Market for produce & -0.114 & 0.503 & 0.821 & -0.013 & -0.123 & 0.506 & 0.807 & -0.014 \\
\hline Member of farmer association & -0.569 & 0.316 & 0.072 & -0.067 & -0.648 & 0.325 & 0.047 & -0.075 \\
\hline $\begin{array}{l}\text { Level of income from farming in Uganda } \\
\text { shillings }\end{array}$ & 0.314 & 0.145 & 0.031 & 0.037 & 0.306 & 0.147 & 0.038 & 0.036 \\
\hline Engaged in non-farm activities & 0.344 & 0.261 & 0.186 & 0.04 & 0.344 & 0.263 & 0.191 & 0.039 \\
\hline Farming duration years & 0.064 & 0.172 & 0.709 & 0.008 & 0.089 & 0.174 & 0.605 & 0.01 \\
\hline Land ownership & 0.478 & 0.434 & 0.270 & 0.056 & 0.557 & 0.447 & 0.213 & 0.065 \\
\hline Size of land in acres & 0.099 & 0.168 & 0.557 & 0.012 & 0.169 & 0.177 & 0.340 & 0.019 \\
\hline Land tenure & 0.168 & 0.128 & 0.895 & 0.002 & -0.004 & 0.129 & 0.973 & 0.010 \\
\hline $\begin{array}{l}\text { Access to soil conditioner (Other than the } \\
\text { MSW compost) }\end{array}$ & 1.655 & 0.347 & 0.000 & 0.194 & 1.639 & 0.35 & 0.000 & 0.191 \\
\hline $\begin{array}{l}\text { Experience with compost fertilizer (time of } \\
\text { utilization in years) }\end{array}$ & 0.369 & 0.973 & 0.000 & 0.043 & 0.369 & 0.098 & 0.000 & 0.043 \\
\hline The cost per kg of compost & -1.394 & 0.14 & 0.000 & -0.164 & -1.41 & 0.142 & 0.000 & -0.164 \\
\hline Market for produce & -0.114 & 0.503 & 0.821 & -0.013 & -0.123 & 0.506 & 0.807 & -0.014 \\
\hline Observations & 358 & & & & 359 & & & \\
\hline Log likelihood & -76.64 & & & & -74.77 & & & \\
\hline LR Chi2 (19) & $336.55^{* * *}$ & & & & $334.57^{* * *}$ & & & \\
\hline Prob > chi2 & 0.001 & & & & 0.001 & & & \\
\hline Pseudo R2 & 0.69 & & & & 0.68 & & & \\
\hline
\end{tabular}

$\mathrm{dy} / \mathrm{dx} \mathrm{b}^{\mathrm{b}}=$ Marginal effect after Probit evaluated at population average and ${ }^{* * *}$ Indicate significance at the $1 \%$ level of significance. $\mathrm{m} \mathrm{p}$ values are in bold 
about compost as reported by Danso et al. (2006) among urban and peri-urban farmers in Accra, Ghana, and a lack of awareness about the benefits of compost for soil fertility (Dandeniya and Caucci 2020). From a practical point of view, these findings as well as our study emphasize the need to strengthen extension programmes and training on compost use, provision of long-term compost price subsidy program through operational tax waivers and provision of transport to resource-constrained smallholder farmers especially in areas with weak commercial fertiliser distribution networks as already being implemented in Western Kenya (Makau et al. 2016) and improving quality through compost segregation in urban areas of Uganda.

The Probit regression model showed how the significant factors would predict the future use of the MSW compost by farmers. The findings indicated that a unit increase in a farmer joining a farmer association in Mbarara leads to a $7.5 \%$ decrease in the probability of farmers' decisions to use MSW compost, contrary to the expected benefits of group membership, where farmers are empowered to achieve higher yields. This is contrary to a study carried out in Nepal (Kumar et al. 2020) where membership to cooperative associations positively influenced farmers' decision to use improved agricultural technologies and extension services. The study also showed that a unit increase in the level of income from farming increases the chances of a farmer using MSW compost by $3.7 \%$ and $3.6 \%$ in Fort Portal and Mbarara, respectively. A farmer earning from his produce is motivated to invest in productivity improvement technologies (e.g., purchase of inputs), resulting in improved utilization of compost (Singh et al. 2016). Furthermore, a unit increase in accessibility to other soil conditioners lead to a $19.4 \%$ and $19.1 \%$ increase in the likelihood of farmers using MSW compost in Fort Portal and Mbarara, respectively. This means that farmers who have access to other types of soil enhancers have a high likelihood of using MSW compost. However, a previous study conducted in Mbarara district in 2013 shows that farmers are likely to abandon the use of fertilizers because of ease of accessibility to livestock dung (Kasirye 2013). This study also showed that an increase in the price of the MSW compost would lead to a $16.4 \%$ reduction in level of farmer's decision to use MSW compost in both Fort Portal and Mbarara municipalities. This is because most farmers already had a fixed amount of money (fee set by the municipal council at the launch of the compost plants) they were willing to pay for the MSW compost. Therefore, any increase in the amount beyond the municipal price may lead to a decrease in its use. This finding is similar to studies of Blessing et al. (2010) in Imo State,
Nigeria which found that the price of fertilizer was a significant determinant of a farmer's decision to adopt or not to adopt the use of fertilizer. Finally, this study also revealed that the experience a farmer had in using any soil conditioner had a positive significant relationship with farmers' decision to use MSW compost. This finding is consistent with studies conducted in Brazil (Morello et al. 2018) where the level of experience with fertilizers had a positive and significant effect on fertilizer adoption. An increase by a year of experience in the use of fertilizers by a farmer leads to a $4.3 \%$ increase in the level of farmer decision to use MSW compost in both Fort Portal and Mbarara municipalities. Farming experience increases the likelihood of farmers using the compost as experienced farmers have much knowledge and also information about the success and failure of using fertilizers than farmers with less experience.

\section{Conclusion and policy implications}

This study explored the level of utilization and the factors affecting the farmers' decision to use MSW compost from the CDM plants in two urban areas of Uganda. Results showed that the level of utilization of MSW compost in both municipalities is generally low. Results obtained from the probit model showed that annual farm income, access to a soil conditioner, experience with the use of fertilizers positively influenced farmers' decision to use MSW compost while the price of MSW compost and membership in a farmers' group negatively influenced farmers' decision to use MSW compost. The negative influence of group membership on the use of MSW compost in Mbarara, should be a concern to policymakers in a country that currently invests in agricultural extension through groups such as that under the Operation Wealth Creation Scheme. Overall, the findings of this study suggest the need for government to create an enabling environment by investing in policies aimed at improving accessibility to soil conditioners, creating opportunities that maximize income from households, interventions focused on the farmer-to-farmer experience sharing, improved dissemination of information through extension programmes and other innovative communication approaches harnessing the benefits of digital tools, and long-term subsidy schemes for the price of compost through operational tax waivers and provision of transport for farmers in urban areas of Uganda. Finally, to guarantee quality and to improve adoption of compost generated at the CDM plants in Uganda, there is a need for research on supply chain analysis and CDM plant operators to invest in research on the quality of MSW compost generated at their facility, conduct cost-benefit analysis of compost application and therefore set a price commensurate with quality, and develop guidelines and rates of application of the MSW compost. Furthermore, a market research using the new product 
design (Urban and Hauser 1993) should be conducted focusing on farmer perception, preference and adaptive conjoint measurement (tradeoff) analysis. This analysis will help the CDM plant operators to tailor their products and services to different customer segments in quality (price setting, etc.) and therefore address the issue of famer perception about fertilisers.

\section{Acknowledgements}

We also appreciate Gulu University Research and Ethics Committee (GUREC) and the Uganda National Council for Science and Technology (UNCST) for granting the permission to undertake this study. We appreciate the efforts of the enumerators, local leaders and respondents in Fort Portal and Mbarara Municipalities who accepted to participate in the study. Views expressed herein do not necessarily reflect the official opinion of the funders

\section{Authors' contributions}

All authors have participated sufficiently in the work and take responsibility for the content, including participation in the concept, design, analysis, writing, or revision of the manuscript. Conception and design of study: KJK, EO, GMM, JCWO. Acquisition of data: KJK, GMM. Analysis and/or interpretation of data: KJK, EO, GMM. Drafting the manuscript: KJK, GMM. Revising the manuscript critically for important intellectual content: KJK, EO, GMM. Approval of the version of the manuscript to be published: KJK, JCWO, EO, GMM. All authors read and approved the final manuscript.

\section{Funding}

This work was partially supported by the Regional Universities Forum for Capability Building in Agriculture (RUFORUM).

\section{Availability of data and materials}

Data and materials for this study are available from the corresponding author upon request.

\section{Declarations}

\section{Ethics approval and consent to participate}

The ethical approvals were obtained from Gulu University Research and Ethics Committee (GUREC) and the Uganda National Council for Science and Technology (UNCST), prior to the data collection. Permission was also obtained from Fort Portal and Mbarara Municipal Council authorities before commencement of the study. Participation in the study was voluntary and written consent was obtained from participants prior to the interviews and all data were collected through their consents.

\section{Consent for publication}

Not applicable.

\section{Competing interests}

Not applicable.

\section{Author details}

'Department of Agronomy, Faculty of Agriculture and Environment, Gulu University, P. O. Box 166, Gulu, Uganda. ${ }^{2}$ Department of Biology, Faculty of Science, Gulu University, P.O.Box 166, Gulu, Uganda. ${ }^{3}$ Department of Agricultural Production, College of Agricultural and Environmental Sciences, Makerere University, P. O. Box 7062, Kampala, Uganda.

Received: 3 June 2021 Accepted: 6 December 2021 Published online: 23 December 2021

\section{References}

Abebe G, Debebe S. Factors affecting use of organic fertilizer among smallholder farmers in Sekela district of Amhara region, Northwestern Ethiopia. Cogent Food Agric. 2019;5(1):1669398.
Akpan SB, Udoh EJ, Nkanta VS. Factors influencing fertilizer use intensity among smallholder crop farmers in Abak agricultural zone in Akwa Ibom State, Nigeria. J Biol Agric Healthcare. 2012;2(1):54-65.

Ali EB, Awuni JA, Danso-Abbeam G. Determinants of fertilizer adoption among smallholder cocoa farmers in the Western Region of Ghana. Cogent Food Agric. 2018;4(1):1538589.

Anang BT. A probit analysis of the determinants of fertilizer adoption by cocoa farmers in Ghana. Asian J Agric Extension Econ Sociol. 2016;8:1-8.

Aryampa S, Maheshwari B, Sabiiti E, Bateganya NL, Bukenya B. Status of waste management in the East African Cities: Understanding the drivers of waste generation, collection and disposal and their impacts on Kampala City's sustainability. Sustainability. 2019;11(19):5523.

Assefa A, Gezahegn A. Adoption of improved technology in Ethiopia. 2009, p. $155-80$.

Babasola OJ, Olaoye IJ, Alalade OA, Matanmi BM, Olorunfemi OD. Factors affecting the use of organic fertilizer among vegetable farmers in Kwara State Nigeria. Tanzania J Agric Sci. 2018;16(1):46-53.

Blessing A, Chiedozie E, Victoria A. Factors influencing the use of fertilizer in arable crop production among smallholder farmers in Owerri agricultural zone of Imo State. Academia Arena. 2010;2(6):6.

Dandeniya WS, Caucci S. Composting in Sri Lanka: policies, practices, challenges, and emerging concerns. In: Organic waste composting through nexus thinking. 2020, p. 61-89.

Danso G, Drechsel P, Fialor S, Giordano M. Estimating the demand for municipal waste compost via farmers' willingness-to-pay in Ghana. Waste Manage. 2006;26(12):1400-9.

Danso GK, Otoo M, Ekere W, Ddungu S, Madurangi G. Market feasibility of faecal sludge and municipal solid waste-based compost as measured by farmers' willingness-to-pay for product attributes: Evidence from Kampala, Uganda. Resources. 2017;6(3):31.

Diacono M, Montemurro F. Long-term effects of organic amendments on soil fertility. Sustain Agric. 2011;2:761-86.

Greene WH. Econometric analysis. 4th ed. International edition: Prentice Hall; 2000. p. 201-15.

Huang Z, Karimanzira TT. Investigating key factors influencing farming decisions based on soil testing and fertilizer recommendation facilities (STFRF) - a case study on rural Bangladesh. Sustainability. 2018;10(11):4331.

Kaizzi, K. Application of the GYGA Approach to Uganda. 2014. http://www. yieldgap.org/gygamaps/excel/GygaUganda.xlsx. Accessed 23 Aug 2021.

Kasirye I. Constraints to agricultural technology adoption in Uganda: evidence from the 2005/06-2009/10 Uganda National panel survey; 2013.

Komakech AJ. Urban waste management and the environmental impact of organic waste treatment systems in Kampala, Uganda. Doctoral thesis, Swedish University of Agricultural Sciences, Uppsala and Makerere University, Kampala; 2014a.

Komakech AJ, Banadda NE, Kinobe JR, Kasisira L, Sundberg C, Gebresenbet G, Vinnerås B. Characterization of municipal waste in Kampala, Uganda. J Air Waste Manage Assoc. 2014b;64(3):340-8.

Krejcie RV, Morgan DW. Determining sample size for research activities. Educ Psychol Measur. 1970;30(3):607-10.

Kumar A, Takeshima H, Thapa G, Adhikari N, Saroj S, Karkee M, Joshi PK. Adoption and diffusion of improved technologies and production practices in agriculture: insights from a donor-led intervention in Nepal. Land Use Policy. 2020;95:104-621.

Lederer J, Ongatai A, Odeda D, Rashid H, Otim S, Nabaasa M. The generation of stakeholder's knowledge for solid waste management planning through action research: a case study from Busia. Uganda Habitat Int. 2015;50:99-109.

Li H, Huang D, Ma Q, Qi W, Li H. Factors influencing the technology adoption behaviours of litchi farmers in China. Sustainability. 2020;12(1):271.

Makau JM, Irungu P, Nyikal RA, Kirimi LW. An assessment of the effect of a national fertiliser subsidy programme on farmer participation in private fertiliser markets in the North Rift region of Kenya. Afr J Agric Resour Econ. 2016;11:292-304.

Martey E, Wiredu AN, Etwire PM, Fosu M, Buah SS, Bidzakin J, Ahiabor BD, Kusi F. Fertilizer adoption and use intensity among smallholder farmers 
in Northern Ghana: a case study of the AGRA soil health project. Sustain Agric Res. 2014. https://doi.org/10.5539/sar.v3n1 p24.

Massah J, Azadegan B. Effect of chemical fertilizers on soil compaction and degradation. Agric Mechan Asia Africa Latin Am. 2016;47(1):44-50.

Melesse B. A review on factors affecting adoption of agricultural new technologies in Ethiopia. J Agric Sci Food Res. 2018;9(3):1-4.

Mensah M, Villamor G, Vlek PL. Gender specific determinants of inorganic fertilizer adoption in the semi-arid region of Ghana. West Afr J Appl Ecol. 2018:26:179-92.

Menyuka N, Bob U, Sibanda M. Potential for organic waste utilization and management through urban agriculture. In: 56th annual conference of the agricultural economics association of South Africa; 2018, p. 1-21

MoLHUD (Ministry of Lands, Housing and Urban Development). The Uganda National Urban Policy. National Land Policy. 2017:91. https:// mlhud.go.ug/wp-content/uploads/2019/07/National-Urban-Policy2017-printed-copy.pdf. Accessed 14 Nov 2021.

Morello TF, Piketty MG, Gardner T, Parry L, Barlow J, Ferreira J, Tancredi NS. Fertilizer adoption by smallholders in the Brazilian amazon: farm-level evidence. Ecol Econ. 2018;144:278-91.

Mukai S. Data on farmers' determinants of manure and inorganic fertiliser use in the semi-arid Ethiopian Rift Valley. Data Brief. 2017;14:804-12.

Mwangi M, Kariuki S. Factors determining adoption of new agricultural technology by smallholder farmers in developing countries. J Econ Sustain Dev. 2015;6(5):208-16.

Nagler J. Interpreting probit analysis. New York: New York University; 1994.

Nambiro E, Okoth P. What factors influence the adoption of inorganic fertilizer by maize farmers? A case of Kakamega District, Western Kenya. Sci Res Essays. 2013;8(5):205-10.

Nazziwa-Nviiri L, Van Campenhout B, Amwonya D. Stimulating agricultural technology adoption: lessons from fertilizer use among Ugandan potato farmers. Intl Food Policy Res Inst. 2017.

NEMA (National Environment Management Authority): Annual performance report for $2016 / 2017 ; 2017$. https://nema.go.ug/sites/default/files/ NEMA\%20Corporate\%20Report\%202016-17_0.pdf. Accessed 23 Aug 2021.

Nigmatullin RR. Strongly correlated variables and existence of a universal distribution function for relative fluctuations. Phys Wave Phenomena. 2008; 16(2):119-45.

Nigussie A, Kuypger TW, de Neergaard A. Agricultural waste utilisation strategies and demand for urban waste compost: evidence from smallholder farmers in Ethiopia. Waste Manage. 2015;1(44):82-93.

Noreen E. An empirical comparison of probit and OLS regression hypothesis tests. J Account Res. 1988;1:119-33.

Nsimbe P, Mendoza H, Wafula ST, Ndejjo R. Factors associated with composting of solid waste at household level in Masaka municipality, Central Uganda. J Environ Public Health. 2018;19:2018.

Ojo JA, Olowoake AA, Obembe A. Efficacy of organomineral fertilizer and un-amended compost on the growth and yield of watermelon (Citrullus lanatus Thumb) in Ilorin Southern Guinea Savanna zone of Nigeria. Int J Recycl Organ Waste Agric. 2014;3(4):121-5.

Okello-Oleng C, Zake JY, Ofrio-Odongo J, Banagieja J, Kofri Asomoa G, Alim Miam M. A suggested National soils policy for Uganda.1992. Available from: https://agris.fao.org/agris-search/search.do?recordID=XF9432227. Accessed 23 Aug 2021.

Okot-Okumu J, Nyenje R. Municipal solid waste management under decentralisation in Uganda. Habitat Int. 2011;35(4):537-43.

Roba TB. Review on: the effect of mixing organic and inorganic fertilizer on productivity and soil fertility. Open Access Library J. 2018;5(06):1 .

Rogger C, Beaurain F, Schmidt TS. Composting projects under the clean development mechanism: sustainable contribution to mitigate climate change. Waste Manage. 2011;31(1):138-46.

Romero C, Ramos P, Costa C, Márquez MC. Raw and digested municipal waste compost leachate as potential fertilizer: comparison with a commercial fertilizer. J Clean Prod. 2013;15(59):73-8.

Sabiiti EN, Katongole CB. Urban agriculture: a response to the food supply crisis in Kampala City, Uganda. In the security of water, food, energy and liveability of cities; 2014, p. 233-42.

Sabiiti EN, Katongole CB. Role of Peri-urban areas in the food system of Kampala, Uganda. In Balanced urban development: options and strategies for liveable cities; 2016, p. 387-92.
Saghir J, Santoro J. Urbanization in Sub-Saharan Africa. In meeting challenges by bridging stakeholders. Washington: Center for Strategic \& International Studies; 2018.

Savci S. Investigation of effect of chemical fertilizers on environment. APCBEE Proc. 2012;1:287-92.

Sebopetji TO, Belete A. An application of probit analysis to factors affecting small-scale farmers' decision to take credit: a case study of the Greater Letaba local Municipality in South Africa. Afr J Agric Res. 2009;4(8):718-23.

Singh DV, Mishra A, Singh SR. The extent of adoption of the market intelligence among the summer cabbage growers. Int J Human Soc Sci Invent. 2016;5(7):67-70.

Tweib SA, Rahman R, Kalil MS. A literature review on the Composting. Int Conf Environ Ind Innov IPCBEE. 2011:12:24-127.

Uganda Bureau of Statistics 2016. The national population and housing census 2014 - main report, Kampala, Uganda. https://www.ubos.org/wp-conte nt/uploads/publications/03_20182014_National_Census_Main_Report. pdf. Accessed 13 Dec 2021

UBOS (Uganda Bureau of Statistics). Annual agricultural survey. https://www. ubos.org/wpcontent/uploads/publications/AAS_2018_Report_Final_ 050620.pdf. 2018

Udeigwe TK, Teboh JM, Eze PN, Stietiya MH, Kumar V, Hendrix J, Mascagni HJ Jr, Ying T, Kandakji T. Implications of leading crop production practices on environmental quality and human health. J Environ Manage. 2015;151:267-79

Udimal TB, Jincai Z, Mensah OS, Caesar AE. Factors influencing the agricultural technology adoption: the case of improved rice varieties (Nerica) in the Northern Region, Ghana. J Econ Sustain Dev. 2017:8(8):137-48.

Ullah A, Khan D, Zheng S, Ali U. Factors influencing the adoption of improved cultivars: a case of peach farmers in Pakistan. Ciência Rural. 2018;14:48.

Urban GL, Hauser JR. Design and marketing of new products. Prentice-Hall. Second Edition. 1993

Wortmann CS, Eledu CS. Uganda's agroecological zones: a guide for planners and policy makers [online]. Centro Internacional de Agricultura Tropical (CIAT), Kampala, Uganda; 1999, p. 55.

Wu L, Jiang Y, Zhao F, He X, Liu H, Yu K. Increased organic fertilizer application and reduced chemical fertilizer application affect the soil properties and bacterial communities of grape rhizosphere soil. Sci Rep. 2020;10(1):1-10.

Zhou Y, Yang H, Mosler HJ, Abbaspour KC. Factors affecting farmers' decisions on fertilizer use: a case study for the Chaobai watershed in Northern China. Consilience. 2010;1(4):80-102.

\section{Publisher's Note}

Springer Nature remains neutral with regard to jurisdictional claims in published maps and institutional affiliations.

Ready to submit your research? Choose BMC and benefit from:

- fast, convenient online submission

- thorough peer review by experienced researchers in your field

- rapid publication on acceptance

- support for research data, including large and complex data types

- gold Open Access which fosters wider collaboration and increased citations

- maximum visibility for your research: over 100M website views per year

At BMC, research is always in progress.

Learn more biomedcentral.com/submissions 